\title{
Online Teaching Barriers, Motivations, and Stress of In-Service Teachers: Renewed Challenges and Opportunities with Future Perspectives
}

\author{
Hyun Seon Ahn \\ Korea University, Seoul, Republic of Korea \\ Pauline Anne Therese M. Mangulabnan \\ National Institute of Technology, Fukui College, Fukui, Japan \\ Jeesoo Lee ${ }^{*}$ \\ University of Seoul, Seoul, Republic of Korea
}

\begin{abstract}
COVID-19 has caused drastic changes to almost all aspects of daily life, with education being the center of these changes and concerns. In particular, teaching approaches have been rapidly reoriented to online versions. Although there is a growing body of literature exploring the views of education during this crisis, a critical need exists to document challenges confronting educators in online teaching. In this paper, we explore the online teaching barriers and motivations of 55 in-service teachers in the Philippines, and how these variables contributed to their perceptions of stress regarding online teaching immediately after the pandemic started. Results demonstrated that respondents' perceptions of interest in online teaching significantly reduced their perceptions of stress regarding online teaching. However, barriers to online teaching, online communication self-efficacy, and the utility value of online teaching perceived by respondents positively predicted their perceptions of stress regarding online teaching. Furthermore, this paper discusses the future perspectives of online teaching transformation based on expectancy-value and self-efficacy theories. Especially, the findings of this paper provide a first look at the stress mechanisms of in-service teachers and initial information regarding stress reduction and professional development of in-service teachers in online teaching.
\end{abstract}

Keywords: education during COVID-19; online teaching barriers; online teaching stress; teacher motivation

\footnotetext{
*Corresponding author: Jeesoo Lee, heartsease0704@gmail.com
} 


\section{Introduction}

With the outbreak of the coronavirus disease (COVID-19), education has undergone drastic changes within the education system in order to minimize the disruption of teaching and learning. The COVID-19 crisis has forced educators to reorient their teaching approaches rapidly into online versions and acclimatize to the dominance of online teaching. With the abrupt migration to online teaching, educators have reported difficulties in control regarding the assessment for learning, compatibility issues for practical-based subjects, and heavy increments in workload (Adedoyin \& Soykan, 2020; Pokhrel \& Chhetri, 2021). While an increasing number of studies have promulgated views of education and its challenges during this crisis, only a few so far have attempted to explore the unique psychological mechanism that underlies the experiences educators have in the immediate conversion to online teaching (MacIntyre et al., 2020). For instance, MacIntyre et al. (2020) found that online teaching amid the COVID-19 pandemic has increased psychological stress-related emotions and the use of avoidance coping strategies.

However, MacIntyre et al. (2020) suggested that there is yet room for improvement in understanding the multidimensional nature of the stressors, and a critical need exists to document alternative approaches for educators to consider in overcoming resistance resulting from barriers to online teaching. In this paper, we discern the levels and the dynamics of psychological challenges that in-service teachers experience due to the unanticipated changes in the instructional methods. Particularly, given that an individual's competence beliefs, such as self-efficacy (Bandura, 1997) and task values (Eccles, 1983; Eccles \& Wigfield, 2002), are important motivational predictors of their emotions and behaviors (Wigfield \& Eccles, 2020), we focused on how these motivational factors, along with online teaching barriers, differentially contribute to the stress levels perceived by teachers.

\subsection{Shifting Policies as a Result of the Pandemic in the Philippines}

The education system of the Philippines most closely resembles that of the United States of America in its adoption of American English as the medium of instruction. In recent years, the Philippines has undergone a major overhaul of its education system, extending the basic education curriculum from 10 to 13 years (from kindergarten to Grade 12; also known as K-12) to bring it in line with the education systems of other Asian countries. With this recent expansion of required school years, the education system has posed more inclusive challenges as such in the material development, training, and teacher preparation. These challenges might act as a hindrance to the quality of education, which might also account for the poor development of qualities of teachers.

Policymakers in the Philippines have recognized that the weakest link in the Philippine education system is the poor quality of education that teachers receive from tertiary education ("Gatchalian Seeks Probe", 2020). They were also aware of the fact that the poor quality of education is manifesting in a considerably low passing rate of licensure examinations for both elementary and secondary teachers ("Gatchalian Seeks Probe", 2020). With the newly minted K- 
12 Curriculum in the Philippines, moreover, the Department of Education carried out English proficiency tests and process skills tests in the subjects of science and mathematics to ensure the quality of teacher education. Although the total results of the quality assurance examination of Grades 7 to 10 teachers in 2016 and 2017 showed $85 \%$ of the 64,008 takers got a nearly proficient score, the results of the Written Expression subtest of those Grades 7 to 10 teachers showed only $58 \%$ of 40,707 Grades 7 and 8 teachers in 2016 and 36\% of 23,301 Grades 9 and 10 teachers in 2017 received a nearly proficient score (Alvis, 2019). In addition to that, the recent education system is inextricably intertwined with new modalities of teaching, especially during the pandemic, and forced teachers to scramble to shift from traditional methods to the online-based approach of teaching and learning within days (Republic of the Philippines Department of Education, 2020). This massive unplanned transition has forced teachers to adjust themselves to the new modalities without being given enough time for gaining experience (Magsambol, 2021). The emergent remote teaching and learning experience, in turn, has left various problems, such as distribution and retrieval of materials, limited access to facilities and technology, psychological stress, and following up on student progress (Castroverde \& Acala, 2021; Cho et al., 2021). Until the opening of classes in January 2022, the Philippines will not have face-to-face classes; hence, there is a need to understand how the new modalities of learning are causing feelings of stress and a desire for rewards incentives among teachers, especially in online learning.

\subsection{The Connection Between Teaching Barriers and Stress}

Teaching is recognized as a highly demanding yet highly rewarding job (Schipor \& Duca, 2021). Research has found that most teachers reported high levels of stress (Kyriacou \& Chien, 2004) and perceive their job as the most stressful profession compared to other jobs (MacIntyre et al., 2020). Uncertainty, isolation, and a sense of powerlessness have been identified as the main stressors to threaten teachers' sense of professional self-esteem, while lack of adequate rewards and societal recognition are known to increase teachers' feelings of self-doubt (Ashton et al., 1983). It seems likely that teachers may experience stress when the demands of the situation exceed their ability to cope with these demands.

Teachers facing online learning difficulties during the COVID-19 era also experience medium to high levels of stress (Klapproth et al., 2020). Studies related to online teaching during the COVID-19 pandemic have consistently reported that uncertainty, heavy workload, and sudden changes in routine teaching procedures increased stress levels (Anderson et al., 2021; MacIntyre et al., 2020). In addition, further online teaching experiences then resulted in burdens to sustain good teaching quality in online learning environments. Proficient use of online teaching tools has become more important than ever as an indicator of competent teachers because it enables teachers to communicate with students clearly and effectively. In the process of adopting this sudden change in the environment, teachers' positive attitudes toward online teaching would, therefore, be expected to be major components that preserve both the quality of teaching and the psychological well-being of teachers. While a wide span of literature related to online teaching during the pandemic focuses on the causes and consequences of 
teacher stress, only limited research has, however, explored the psychological mechanisms teachers experience in online teaching tasks.

\subsection{The Connection Between Self-Efficacy and Values, and Stress}

Self-efficacy refers to the subjective conviction about one's capabilities to achieve the tasks required to meet the desired outcomes (Bandura, 1997). The research on self-efficacy has suggested that self-efficacy beliefs as perceived by teachers as well as students play a central role in predicting engagement, persistence, and outcomes in diverse achievement-related contexts (Honicke \& Broadbent, 2016; Schunk, 1991). For instance, teachers with stronger self-efficacy beliefs tend to pursue higher levels of teaching-related outcomes and skills (cf. Schwarzer \& Hallum, 2008; Tschannen-Moran \& Hoy, 2001), perceive low levels of burnout and stress (Fathi et al., 2021; Herman et al., 2020; Schwarzer \& Hallum, 2008), and be associated with higher job satisfaction (Granziera \& Perera, 2019). In the same context, communication self-efficacy is significantly related to overall online learning and tendency to continue enrolment in online learning (Chu, 2010).

During the COVID-19 pandemic, however, online teaching is the only panacea for both teachers and students to ensure the continuity of teaching and learning. Given the limited availability of training and preparation, and a high possibility of a shortage of resources, teachers have reported being overwhelmed, unsure, and pressured about online teaching and assessment (Adedoyin \& Soykan, 2020; Pokhrel \& Chhetri, 2021). Others have also reported severe psychological stressrelated emotions and resultant avoidance coping strategies in online teaching during the pandemic era (MacIntyre et al., 2020). Pressley et al. (2021) also assumed that teachers feeling anxious about online teaching may be attributed to differences in their self-efficacy in using technology and lack of previous experience. Despite a clear record of a relationship between teacher self-efficacy and its relevant psychological and emotional constructs, limited information is available to understand the psychological mechanisms involved in pathways from motivation to stress that teachers experience during the pandemic era. Apart from that, researchers have indicated that value beliefs regarding the tasks at hand can be another crucial type of motivation for individuals' behavioral and emotional outcomes in achievement contexts (Wigfield \& Eccles, 2020). Results from empirical studies consistently confirm that those individuals holding high task values tend to exert more effort (Guo et al., 2016) and report a strong linkage with career aspirations and course choice (Durik et al., 2006).

According to Eccles and Wigfield's Situative Expectancy-Value Model (Eccles \& Wigfield, 2020; Wigfield \& Eccles, 2020), the value of a task is a function of three specific value components: intrinsic, attainment, and utility values. Although these are assumed to be differentiated both conceptually and empirically (Eccles \& Wigfield, 1995), the distinction between attainment value and utility value tends to vary depending on the goals of tasks. As such, the two concepts of attainment value and utility value are less differentiated when the goals of tasks are highly important (Wigfield \& Eccles, 2020).

Research findings have indicated empirical links between specific value beliefs and emotional outcomes with a focus on negative emotions, such as worry about 
performance (Hong et al., 2015) and test stress (Lee et al., 2013). Intrinsic value or its relevant construct, such as interest, has been found to show negative relations with negative emotions (cf. Lohbeck et al., 2016). However, results about the role played by utility value in predicting negative outcomes in previous research are relatively lacking and less consistent. Among them, results addressing teachers' value beliefs about online teaching are even more limited, which supports the current need of investigation. One recent research study targeting pre-service teachers' beliefs about using technology in teaching revealed that pre-service teachers' intrinsic value and utility value were negatively associated with their perception of emotional cost regarding the use of technology for teaching (Ranellucci et al., 2020).

Although value components including utility value are assumed theoretically to be motivational predictors that positively predict adaptive outcomes (Wigfield \& Eccles, 2020), a few recent studies targeting students has reported that utility value has weak but positive relations with negative emotions (cf. Hong et al., 2015). For example, in Lauermann et al.'s (2017) study targeting students in the United States, worry about performance was positively correlated with utility value, whereas its relations with intrinsic value was nonsignificant in the domain of mathematics. Given the increased importance of online teaching during the pandemic, the present study may be deemed as important for illuminating how emerging value perspectives in online teaching affect the motivational and psychological mechanisms of teachers. The present study attempts to provide an understanding of the relations of values with negative emotional outcomes and how this may tend to vary depending on the specific value component focusing on intrinsic value and utility value.

\subsection{The Present Study}

In the present study, we investigate the extent of teachers' perceptions of stress, online teaching barriers, and motivations in regard to online teaching. Particularly, our focus is on exploring teachers' psychological reactions to the suddenly enforced new teaching methods immediately following the pandemic. We also examine the roles played by teachers' perceptions of online teaching barriers and motivations in explaining their perceptions of stress. Generally, we expected that online teaching barriers, self-efficacy, and the two types of task values would be strong predictors of perceived stress. More specifically, we expected that perceived stress would be predicted positively by online teaching barriers and negatively by self-efficacy and intrinsic value. Although specific expectations about the nature of the role played by utility value in predicting negative outcomes are limited in the literature, we hypothesize that utility value would be a positive predictor of perceptions of stress based on the aforementioned results.

\section{Methods}

\subsection{Respondents and Procedure}

An online survey was administered to explore in-service teachers' perceptions of working and teaching online during the pandemic. An online questionnaire was developed to collect the required data and its survey link distributed via electronic 
mail to the potential respondents. The convenience sampling technique was employed to secure the potential respondents, who resided in the Philippines as in-service teachers and were scheduling urgent professional development programs to conduct online classes during the time of the research (i.e., the Fall-Winter semester of 2020). They were about to do hybrid learning modalities for the first time and had experienced limited challenges during the pandemic.

An initial invitation letter describing the study and seeking respondents was emailed to 70 potential respondents who had attended separate online seminars (i.e., on different modes of learning) by one of the authors of this paper. The respondents were asked to complete the online questionnaire in English, which is the common language among all respondents, within two weeks of receiving the invitation letter, and no one expressed any encountered technical problems in completing the questionnaire. A total of 55 Filipino in-service teachers (female $=$ 33 and male $=22$; mean age $=37.49$ ) agreed to participate in the survey by submitting their responses in the anonymous online survey conducted via Google Forms. More specifically, the respondents were from public $(75 \%, \mathrm{n}=41)$ and private $(25 \%, \mathrm{n}=14)$ institutions of the three major islands in the country, and they taught at different levels from preschool level to tertiary level. The majority of the respondents $(47 \%, \mathrm{n}=26)$ were teaching at tertiary level, $27 \%(15)$ were teaching at secondary level, and the rest were teaching lower grade levels, with one teaching out-of-school youth.

\subsection{Measures}

We adapted the questionnaire items for this study based on various sources and measured respondents' perceptions of online teaching barriers, self-efficacy, intrinsic value, utility value, and stress regarding online teaching. Response scales ranged from 1 (strongly disagree) to 5 (strongly agree) for all variables (refer to Appendix 1).

\subsubsection{Online teaching barriers}

We adapted five items from the teacher-level barriers subscale of the E-Learning Implementation Barriers Scale (Mailizar et al., 2020) to measure teachers' perceptions of online teaching barriers (e.g., "The use of e-learning during this pandemic is not convenient for $\left.\mathrm{me}^{\prime \prime}\right)$. Online teaching barriers have been defined as faculty-perceived barriers that exist in resources, knowledge and skills, and attitudes and beliefs (Hew \& Brush, 2007; Lloyd et al., 2012) toward online education during the pandemic. Higher scores reflect greater perceptions of barriers regarding online teaching. A reverse coded item was deleted due to the loss in scale reliability ("I have experience in using e-learning"; $\alpha=.71$ ). Following this, four items were included in the final analysis $(\alpha=.84)$.

\subsubsection{Motivation}

\subsubsection{Self-efficacy}

We adapted four items from the online communication self-efficacy scale (Hung, 2016) to measure online teachers' efficacy beliefs with communication technologies in online teaching (e.g., "I feel confident in using online tools to effectively communicate with students"). The four-item scale showed good reliability $(\alpha=.93)$. 


\subsubsection{Intrinsic value and utility value}

To assess intrinsic value, we used three items modified from those used in Eccles and Wigfield (1995) and Gaspard et al. (2015) (e.g., "In general, I find conducting online classes is interesting"). Higher scores reflect greater intrinsic value perceived by teachers in online teaching $(\alpha=.88)$. We used two items modified from those used in Eccles and Wigfield (1995) to assess utility value (e.g., "Conducting high-quality online classes is useful for achieving my goal as a teacher"). Higher scores reflect greater utility value perceived by teachers toward online teaching $(\alpha=.95)$.

\subsubsection{Stress}

To assess stress, we used three items modified from those used in Putwain and Von der Embse (2019) (e.g., "I have felt increased stress as a result of recent changes of instructional methods from traditional teaching to online teaching"). Higher scores show greater stress regarding instructional changes to online teaching $(\alpha=.89)$.

\subsubsection{Control variables}

As control variables, we assessed respondents' gender; male was coded as 0 and female as 1. We also measured the levels of teaching experience by asking respondents to report the number of years they had been teaching. This was coded as 0 for below 5 years, 1 for $6-10$ years, 2 for 11-15 years, 3 for 16-20 years, and 4 for 21 years and above.

\section{Results}

\subsection{Preliminary Analysis}

Table 1 lists descriptive statistics for and zero-order correlation coefficients between the measured variables.

Table 1. Descriptive statistics and bivariate correlations between observed variables

\begin{tabular}{lccccccc}
\hline & 1 & 2 & 3 & 4 & 5 & 6 & 7 \\
\hline 1. Gendera & - & & & & & & \\
2. Teaching experience & $.30^{*}$ & - & & & & & \\
3. Online teaching barrier & $-.38^{* *}$ & -.15 & - & & & & \\
4. Self-efficacy & -.05 & .16 & -.09 & - & & & \\
5. Intrinsic value & .02 & .05 & -.20 & $.39^{* *}$ & - & & \\
6. Utility value & -.03 & .10 & $-.32^{*}$ & $.34^{*}$ & $.50^{* *}$ & - & \\
7. Stress & -.22 & -.10 & $.42^{* *}$ & .08 & $-.46^{* *}$ & -.02 & - \\
\hline \multicolumn{1}{c}{$M$} & 0.60 & 1.64 & 2.45 & 3.67 & 3.72 & 4.30 & 3.22 \\
\multicolumn{1}{c}{$\mathrm{a}$} & 0.49 & 1.50 & 1.01 & 0.95 & 0.98 & 0.89 & 1.03 \\
& - & - & .84 & .93 & .88 & .95 & .89 \\
\hline
\end{tabular}

Note. $N=55$. Response scales ranged between 1 and 5 for all variables

a $0=$ male, $1=$ female

${ }^{*} p<.05 ;{ }^{* *} p<.01$

The absolute values of both skewness and kurtosis for all variables fell below 2, indicating the assumption that the data follow a normal distribution. As seen in 
Table 1, respondents' perception of stress regarding online teaching was related positively with online teaching barriers $(r=.42, p<.001)$ and negatively with intrinsic value of online teaching $(r=-.46, p<.001)$. There was also a significant negative relation between online teaching barriers and utility value $(r=-.32$, $p<.001)$. Respondents' gender was related positively with the levels of teaching experience $(r=.30, p<.05)$ and negatively with their perception of online teaching barriers $(r=-.38, p<.001)$.

\subsection{Path analysis}

We conducted a path analysis to see whether respondents' perceptions of stress regarding online teaching can be accounted for by their perceptions of online teaching barriers, intrinsic value, utility value, and self-efficacy. The variances explained by respondents' gender and teaching experience in stress were statistically controlled for. Model fit was evaluated based on the comparative fit index (CFI), the Tucker-Lewis index (TLI), and the root mean square error of approximation (RMSEA). The model fit is deemed acceptable with a CFI and TLI greater than .95 (Hu \& Bentler, 1999) and an RMSEA less than .08 (Browne \& Cudeck, 1992). The hypothesized model demonstrated a good fit to the data, with $\chi^{2}(6, N=55)=37.786$ and $\mathrm{p}<.001(\mathrm{CFI}=1.0, \mathrm{TLI}=1.0$, RMSEA $=0)$.

Table 2 presents the unstandardized (B) and standardized coefficients $(\beta)$ and $R^{2}$ values for the research model.

Table 2. Estimated coefficients in the research model predicting stress

\begin{tabular}{lcccc}
\hline \multicolumn{1}{c}{ Variable } & $B$ & $\beta$ & $S E$ & $p$ \\
\hline Gender & -.11 & -.05 & .11 & .636 \\
Teaching experience & .02 & .03 & .10 & .757 \\
Online teaching barriers & .42 & .42 & .11 & $<.001$ \\
Self-efficacy & .26 & .24 & .11 & .025 \\
Intrinsic value & -.68 & -.65 & .11 & $<.001$ \\
Utility value & .45 & .36 & .12 & .002 \\
$R^{2}$ & .50 & & .10 & $<.001$ \\
\hline
\end{tabular}

Note. $N=55$

After controlling for gender and teaching experience, stress perceived by respondents was significantly predicted by online teaching barriers $(\beta=.42$, $p<.001)$, self-efficacy $(\beta=.24, p<.001)$, intrinsic value $(\beta=-.65, p<.001)$, and utility value $(\beta=.36, p<.001)$. Specifically, as the respondents more strongly perceived intrinsic value in conducting online teaching, they showed lower levels of stress regarding the sudden instructional changes to online teaching during the pandemic. However, as the respondents perceived higher barriers to online teaching, stronger communication self-efficacy, and higher utility value about conducting online classes, they tended to perceive higher levels of stress.

\section{Discussion}

Despite much conceptual and empirical work aimed at illuminating the educational crisis caused by and challenges presented by COVID-19 (Amemado, 2020; Donisa-Schmidt \& Ramot, 2020), only a few studies have directly examined 
the major motivational and behavioral determinants and their mechanisms underlying the stress responses from in-service teachers in online teaching positions. This study not only widens the understanding of the impact of the COVID-19 pandemic on online teaching but also deepens the knowledge of how stress perceived by in-service teachers is intertwined with motivational and behavioral determinants in online teaching during the pandemic situation. Specifically, the results of the current study indicate that perceived barriers to online teaching led to increases in stress levels, while intrinsic value functions as a critical motivation to lower stress levels toward online teaching.

The relationship between the perceived barriers in online teaching and the levels of stress was found to be statistically significant for in-service teachers during the pandemic situation. This result is supported by the findings from previous studies (Adedoyin \& Soykan, 2020; Pokhrel \& Chhetri, 2021). Respondents' perceptions of their online teaching, in the context of lack of resources and other barriers such as the use of online programs, indicated relatively high levels of stress and even higher possibilities of facing heavy workloads during the COVID-19 pandemic. The provision of appropriate resources and online teaching professional development courses are necessary for the improvement of the quality of online teaching and reduction of online-related stress. An awareness of online teaching experiences and preparatory experiences may contribute to lessening the stress responses of in-service teachers.

Unexpectedly, however, we found that self-efficacy and utility value tended to increase stress levels in relation to online teaching. On the one hand, the unexpected finding of the effect of self-efficacy can be explained by resource allocation (Yeo \& Neal, 2013) due to growing demands of online teaching during the COVID-19 pandemic. On the other hand, it is also possible that some teachers with higher teaching self-efficacy may be prone to experiencing greater overall stress due to their idealistic goals that cause them to strive for better and more successful performances in their job roles (Reilly et al., 2014). To alleviate this unique condition, teachers need to have enough opportunities to fulfill a diverse range of their career and psychological or developmental needs through professional technological development. However, future investigations are needed to explore these unexpected relationships among self-efficacy, work expectations, and teacher stress in more detail.

The role of utility value as a positive predictor of perceived stress is in line with some previous findings documenting positive relations of utility value to negative emotions perceived by students, such as worry (Hong et al., 2015; Lauermann et al., 2017) and test stress (Lee et al., 2013) in school-related tasks and subject domains. Utility value reflects the most extrinsic aspect of motivation among the three specific values (Wigfield \& Eccles, 2020). While intrinsic motivation, such as interest, plays a positive role in explaining positive behavioral and emotional outcomes (Hidi \& Renninger, 2006; Lipstein \& Renninger, 2006) and helps individuals recover from emotional depletion (Thoman et al., 2011), extrinsic motivation is known to be positively related to an individual's negative emotions, such as depression (Sheehan et al., 2018). It seems possible that the external 
demands in the sudden changes of the teaching medium might have tinged the extrinsic nature of "utility" perception among teachers without having enough time to internalize the beliefs and to find its connection to their goals, such as sustaining teaching quality.

Future researchers are urged to examine how the different availability of resource supplies affects the self-efficacy and utility value judgements and how the relationships between self-efficacy, utility value, and stress may vary after controlling for substantial variance accounted by potential moderators. Given the limitations of a small sample size and one-shot survey design, other methodological approaches are needed. Longitudinal studies can be done with in-service teachers to examine how teacher self-efficacy changes over time and the associated perceived stress during the pandemic. Interviews and observations can be another methodological approach that can provide qualitative research findings of the online teaching experiences and perceptions of in-service teachers in an unusual situation.

Moreover, a larger sample size is needed to identify the different ways that inservice teachers interpret barriers to online teaching depending on the context of online resources provided along with other cultural and ethnic backgrounds. Furthermore, although we focused on intrinsic value and utility value in the present study, how the three value components, including attainment value, would differentially contribute to teachers' perceptions of stress requires further investigation. Particularly, future research should probe into the operational distinction between teachers' perceptions of attainment value and utility value.

Finally, issues related to intervention actions for provision of technology infrastructure and online community-based initiatives for teacher professional development should be unearthed especially because the demand for online teaching will develop even after the pandemic era. A news article even stated that online teaching is inevitable for future education trends and requires a long-term educational system reform alongside policy for teacher professional development (Kalenzi et al., 2020). However, there is limited evidence for the effectiveness of online teaching practices and professional development programs, whereas studies regarding online teaching barriers are plentiful (Hew \& Brush, 2007; Pokhrel \& Chhetri, 2021). Since most previous studies did not take into account multifaceted educational responses to the pandemic era, future research therefore needs to investigate the differences in online teaching barriers encountered by teachers through multiple phases of educational responses during the pandemic. Moreover, future researchers need to undertake professional development programs for teachers in order to augment self-efficacy beliefs and values and reduce stress levels in online teaching at the same time.

\section{Conclusion}

The present study explored the relations of values with negative emotional outcomes and how it may tend to vary depending on the specific value component focusing on intrinsic and utility values in the sudden changes of teaching medium during the pandemic era. This study uniquely examined 
in-service teachers' perceived levels of self-efficacy beliefs and the important roles of intrinsic and utility values, barriers in online teaching, and stress during the pandemic era. Results demonstrated that respondents' intrinsic value in online teaching significantly reduced their perceptions of stress regarding online teaching. However, barriers to online teaching, online communication self-efficacy, and utility value of online teaching perceived by respondents positively predicted their perceptions of stress regarding online teaching. The findings of this study may advance various forms of online teaching transformation and its future perspectives. Specifically, while the small-scale nature of the sample was considered, the findings of this study offer important, novel insights into the stress mechanisms of in-service teachers in online teaching. In addition to that, this study provides initial guidance for stress reduction and professional development of in-service teachers in online teaching based on expectancy-value and self-efficacy theories.

\section{References}

Adedoyin, O. B., \& Soykan, E. (2020). COVID-19 pandemic and online learning: The challenges and opportunities. Interactive Learning Environments, 1-13, https:// doi.org/10.1080/10494820.2020.1813180

Alviz, A. (2019). The language proficiency and process skills of Filipino high school teachers. Education Quarterly Reviews, 2(3), 615-628. https://doi.org/10.31014/aior.1993.02.03.93

Amemado, D. (2020). COVID-19: An unexpected and unusual driver to online education. International Higher Education, 102, 12-14. https://www.internationalhighereducation.net/apiv1/article/!/action/getPdfOfArticle/articleID/2905/productID/29/filename/a rticle-id-2905.pdf

Anderson, R. C., Bousselot, T., Katz-Buoincontro, J., \& Todd, J. (2021). Generating buoyancy in a sea of uncertainty: Teachers creativity and well-being during the COVID-19 pandemic. Frontiers in Psychology, 11, 1-17. https:// doi.org/10.3389/fpsyg.2020.614774

Ashton, P. T., Webb, R. B., \& Doda, N. (1983). A study of teachers' sense of efficacy: Final report execute summary. University of Florida.

Bandura, A. (1997). Self-efficacy: The exercise of control. Freeman.

Browne, M. W., \& Cudeck, R. (1992). Alternative ways of assessing model fit. Sociological Methods \& Research, 21, 230-258. https:/ / doi.org/10.1177/0049124192021002005

Castroverde, F., \& Acala, M. (2021). Modular distance learning modality: Challenges of teachers in teaching amid the COVID-19 pandemic. International Journal of Research Studies in Education, 10(8), 7-15. https:// doi.org/10.5861/ijrse.2021.602

Cho, Y., Kataoka, S., \& Piza, S. F. Y. (2021). Philippine basic education system: Strengthening effective learning during the COVID-19 pandemic and beyond: Philippines COVID-19 monitoring survey policy notes (English) (Report no. 159564). World Bank Group. https://documents.worldbank.org/en/publication/documentsreports/documentdetail/198561622119902647/philippines-covid-19monitoring-survey-policy-notes

Chu, R. J.-c. (2010). How family support and internet self-efficacy influence the effects of e-learning among higher aged adults: Analyses of gender and age differences. $\begin{array}{llll}\text { Computers } & \text { Education, 255-264. }\end{array}$ https://doi.org/10.1016/j.compedu.2010.01.011

Donisa-Schmidt, S., \& Ramot, R. (2020). Opportunities and challenges: Teachers education in Israel in the COVID-19 pandemic. Journal of Education of Teaching, 46(4), 586595. https://doi.org/10.1080/02607476.2020.1799708 
Durik, A. M., Vida, M., \& Eccles, J. S. (2006). Task values and ability beliefs as predictors of high school literacy choices: A developmental analysis. Journal of Educational Psychology, 98(2), 382-393. https:/ / doi.org/10.1037/0022-0663.98.2.382

Eccles, J. S. (1983). Expectancies, values and academic behaviors. In J. T. Spence (Ed.), Achievement and achievement motives (pp. 75-146). Freeman.

Eccles, J. S., \& Wigfield, A. (1995). In the mind of the actor: The structure of adolescents' achievement task values and expectancy-related beliefs. Personality and Social Psychology Bulletin, 21, 215-225. https:// doi.org/10.1177\%2F0146167295213003

Eccles, J. S., \& Wigfield, A. (2002). Motivational beliefs, values and goals. Annual Review of Psychology, 53 ,

109-132. https://doi.org/10.1146/annurev.psych.53.100901.135153

Fathi, J., Greenier, V., \& Derakhshan, A. (2021). Self-efficacy, reflection, and burnout among Iranian EFL teachers: The mediating role of emotion regulation. Iranian Journal of Language Teaching Research, 9(2), 13-37. https://doi.org/10.30466/IJLTR.2021.121043

Gaspard, H., Dicke, A. L., Flunger, B., Schreier, B., Häfner, I., Trautwein, U., \& Nagengast, B. (2015). More value through greater differentiation: Gender differences in value beliefs about math. Journal of Educational Psychology, 107(3), 663-677. https://doi.org/10.1037/edu0000003

Granziera, H., \& Perera, H. N. (2019). Relations among teachers' self-efficacy beliefs, engagement, and work satisfaction: A social cognitive view. Contemporary Educational Psychology, 58, 75-84. https://doi.org/10.1016/j.cedpsych.2019.02.003

Guo, J., Nagengast, B., Marsh, H. W., Kelava, A., Gaspard, H., Brandt, H., Cambria, J., Flunger, B., Dicke, A., Häfner, I., Brisson, B., \& Trautwein, U. (2016). Probing the unique contributions of self-concept, task values, and their interactions using multiple value facets and multiple academic outcomes. AERA Open, 2, 1-20. https://doi.org/10.1177/2332858415626884

Herman, K. C., Prewett, S. L., Eddy, C. L., Savala, A., \& Reinke, W. M. (2020). Profiles of middle school teacher stress and coping: Concurrent and prospective correlats. Journal of School Pscyhology, 78, 54-68. https://doi.org/10.1016/j.jsp.2019.11.003

Hew, K. F., \& Brush, T. (2007). Integrating technology into K-12 teaching and learning: Current knowledge gaps and recommendations for future research. Education Technology Research and Development, 55, 223-252. https://doi.org/10.1007/s11423-006-9022-5

Hidi, S., \& Renninger, K. (2006). The four-phase model of interest development. Educational Psychologist, 41, 111-127. https://doi.org/10.1207/s15326985ep4102_4

Hong, E., Mason, E., Peng, Y., \& Lee, N. (2015). Effects of homework motivation and worry anxiety on homework achievement in mathematics and English. Educational Research and Evaluation, 21, 491-514. https://doi.org/10.1080/13803611.2015.1131721

Honicke, T., \& Broadbent, J. (2016). The influence of academic self-efficacy on academic performance: A systematic review. Educational Research Review, 17, 63-84. https://doi.org/10.1016/j.edurev.2015.11.002

Hu, L. T., \& Bentler, P. M. (1999). Cutoff criteria for fit indexes in covariance structure analysis: Conventional criteria versus new alternatives. Structural Equation $\begin{array}{lllll}\text { Modeling: A } & \text { Multidisciplinary Journal, }\end{array}$ https://doi.org/10.1080/10705519909540118

Hung, M.-1. (2016). Teacher readiness for online learning: Scale development and teacher perceptions. Computer $\mathcal{E}$ Education, 94, 120-133. https://doi.org/10.1016/j.compedu.2015.11.012

Kalenzi, C., Back, D., \& Yim, M. (2020, November 13). The future of online education: Lessons from South Korea. World Economic Forum. 
https://www.weforum.org/agenda/2020/11/lessons-from-south-korea-on-thefuture-of-online-education/

Klapproth, F., Federkeil, L., Heinschke, F., \& Jungmann, T. (2020). Teachers' experiences of stress and their coping strategies during COVID-19 induced distance teaching. Journal of Pedagogical Research, 4(4), 444-452.

Kyriacou, C., \& Chien, P. Y. (2004). Teacher stress in Taiwanese primary schools. Journal of Educational Enquiry, 56-104. https://citeseerx.ist.psu.edu/viewdoc/download?doi=10.1.1.456.1052\&rep=rep $1 \&$ type $=$ pdf

Lauermann, F., Eccles, J. S., \& Pekrun, R. (2017). Why do children worry about their academic achievement? An expectancy-value perspective on elementary students' worries about their mathematics and reading performance. ZDM Mathematics Education, 49, 339-354. https://doi.org/10.1007/s11858-017-0832-1

Lee, J., Lee, M., \& Bong, M. (2013). High value with low perceived competence as an amplifier of self-worth threat. In D. McInerney, H. Marsh, R. Craven, \& F. Guay (Eds.), Theory driving research: New wave perspectives on self-processes and human development (pp. 205-231). Information Age.

Lipstein, R., \& Renninger, K. A. (2006). "Putting things into words": 12-15-year-old students' interest for writing. In P. Boscolo \& S. Hidi (Eds.), Motivation and writing: Research and school practice (pp. 113-140). Kluwer Academic/Plenum Press.

Lloyd, S. A., Byrne, M. M., \& McCoy, T. S. (2012). Faculty-perceived barriers of online education. MERLOT Journal of Online Learning and Teaching, 8(1), 1-12. https://jolt.merlot.org/vol8no1/lloyd_0312.pdf

Lohbeck, A., Nitkowski, D., \& Ptermann, F. (2016). A control-value theory approach: Relationships between academic self-concept, interest, and test anxiety in elementary school children. Child Youth Care Forum, 45, 887-904. https://doi.org/10.1007/s10566-016-9362-1

MacIntyre, P. D., Gregersen, T., \& Mercer, S. (2020). Language teachers' coping strategies during the COVID-19 conversion to online teaching: Correlations with stress, wellbeing and negative emotions. System, 94, 1-13. https://doi.org/10.1016/j.system.2020.102352

Magsambol, B. (2021, July 20). Distance learning in the Philippines: A year of hits and misses. Rappler. https://www.rappler.com/newsbreak/in-depth/distancelearning-philippines-assessment-2020-2021

Mailizar, Almanthari, A., Maulina, S., \& Bruce, S. (2020). Secondary school mathematics teachers' views on e-learning implementation barriers during the COVID-19 pandemic: The case of Indonesia. EURASIA Journal of Mathematics, Science, and Technology Education, 16(7), em1860. https://doi.org/10.29333/ ejmste/8240

Pokhrel, S., \& Chhetri, R. (2021). A literature review on impact of COVID-19 pandemic on teaching and learning. Higher Education for the Future, 8(1), 133-141. https:// doi.org/10.1177/2347631120983481

Pressley, T., Ha, C., \& Learn, E. (2021). Teacher stress and anxiety during COVID-19: An $\begin{array}{llll}\text { empirical study. School Psychology, 36(5), 357-376. } & \end{array}$ https://doi.org/10.1037/spq0000468

Putwain, D. W., \& Von der Embse, N. P. (2019). Teacher self-efficacy moderates the relations between imposed pressure from imposed curriculum changes and teacher stress. Educational Psychology, 39(1), 51-64. https://doi.org/10.1080/01443410.2018.1500681

Ranellucci, J., Rosenberg, J. M., \& Poitras, E. G. (2020). Exploring pre-service teachers' use of technology: The technology acceptance model and expectancy-value theory. Journal of Computer Assisted Learning, 36(6), 810-824. https://doi.org/10.1111/jcal.12459 
Reilly, E., Dhingra, K., \& Boduszek, D. (2014). Teachers' self-efficacy beliefs, self-esteem, and job stress as determinants of job satisfaction. International Journal of Educational Management, 28(4), 365-378. https://doi.org/10.1108/IJEM-04-2013-0053

Republic of the Philippines Department of Education. (2020, July 20). Policy guidelines for the provision of learning resources in the implementation of the basic education learning continuity plan. https://www.deped.gov.ph/wpcontent/uploads/2020/08/DO_s2020_018.pdf

Republic of the Philippines: Philippine News Agency. (2020, September 30). Gatchalian seeks probe on declining quality of teacher education. https://www.pna.gov.ph/articles/1117072

Schipor, M.-D., \& Duca, D.-S. (2021). On-site vs. online teaching: Challenges and coping strategies. Revista Romaneasca pentru Educatie Multidimensionala, 13, 123-136. https:// doi.org/10.18662/rrem/13.1Sup1/388

Schunk, D. H. (1991). Self-efficacy and academic motivation. Educational Psychologist, 26(34), 207-231. https://doi.org/10.1080/00461520.1991.9653133

Schwarzer, R., \& Hallum, S. (2008). Perceived teacher self-efficacy as a predictor of job stress and burnout: Mediation analyses. Applied Psychology: An International Review, 57, 152-171. https://doi.org/10.1111/j.1464-0597.2008.00359.x

Sheehan, R. B., Herring, M. P., \& Campbell, M. J. (2018). Associations between motivation and mental health in sport: A test of the hierarchical model of intrinsic and extrinsic motivation. Frontiers in Psychology, 9, 1-10. https:// doi.org/10.3389/fpsyg.2018.00707

Thoman, D. B., Smith, J. L., \& Silvia, P. J. (2011). The resource replenishment function of interest. Social Psychological and Personality Science, 2, 592-599. https://doi.org/10.1177/1948550611402521

Tschannen-Moran, M., \& Hoy, A. W. (2001). Teacher efficacy: Capturing an elusive construct. Teaching and Teacher Education, 17(7), 783-805. https:// doi.org/10.1016/S0742-051X(01)00036-1

Wigfield, A., \& Eccles, J. S. (2020). 35 years of research on students' subjective task values and motivation: A look back and a look forward. In A. J. Elliot (Ed.), Advances in motivation science (Vol. 7, pp. 161-198). Elsevier. https:// doi.org/10.1016/bs.adms.2019.05.002

Yeo, G. B., \& Neal, A. (2013). Revisiting the functional properties of self-efficacy: A dynamic perspective. Journal of Management, 39(6), 1385-1396. https://doi.org/10.1177/0149206313490027 
Appendix 1

Online Survey Questionnaire via Google Forms

\section{Online Teaching Survey}

Good day!

You are invited to participate in the Online Teaching and coronavirus disease 2019 (COVID-

19) survey.

The purpose of this survey is to examine teachers' perceptions of working and teaching online during COVID-19. Your participation in this survey will contribute to a better understanding of how teachers at different institutions perceive online teaching during COVID-19. This data is used by the researchers anonymously to explore the current readiness and situation of online teaching.

The survey will take approximately 5-10 minutes of your time to complete, although it could take longer depending on your answers. You will involve answering questions about a variety of topics that may include your motivation, difficulty, and stress with online teaching.

If you agree to participate, please complete the form at your earliest convenience. Thank you.

* 필수항목

1. Email address *

2. Gender *

해당 사항에 모두 표시하세요.

Male

Female

3. Age *

(C)Authors

This work is licensed under a Creative Commons Attribution-NonCommercial-NoDerivatives 4.0 International License (CC BY-NC-ND 4.0). 
4. School location *

한 개의 타원형만 표시합니다.

$\underset{\text { Rurban }}{\bigodot}$

5. School type *

한 개의 타원형만 표시합니다.

$\bigcirc$ Public

Private

6. Level of education to teach *

한 개의 타원형만 표시합니다.

$\square$ Elementary
High school
College
기타:

기타:

7. Teaching experience *

한 개의 타원형만 표시합니다.

Below 5 years

6-10 years

11-15 years

16-20 years

21 years and above 
8. Specialization / Academic track

한 개의 타원형만 표시합니다.

Accountancy, Business, and Management (ABM)

General Academic Strand (GAS)

Humanities and Social Science (HUMSS)

Science, Technology, Engineering, and Mathematics (STEM)

N/A

9. Online classes conducted per week *

한 개의 타원형만 표시합니다.

Below 3 days per week

Above 3 days per week

Daily

10. Possess of gadgets for online classes *

한 개의 타원형만 표시합니다.

Own

Provided by School or Government Institution

11. Conducted online classes before COVID-19 Pandemic *

한 개의 타원형만 표시합니다.

$\Longrightarrow$ Yes

$\bigcirc$ No

(c) Authors

This work is licensed under a Creative Commons Attribution-NonCommercial-NoDerivatives 4.0 International License (CC BY-NC-ND 4.0). 
12. Platforms of online classes (Please tick as many as apply.) *

해당 사항에 모두 표시하세요.

$\square$ Mobile-conversation (e.g., WatsAPP, Viber, Line, etc.)

$\square$ Google classroom

$\square$ Team Link

$\square$ YouTube

$\square$ Zoom

$\square$ Skype

$\square$ Google meet

$\square$ Facebook and/or Facebook Messenger

$\square$ Microsoft Teams

Own School Platform

기타:

13. I do not have sufficient knowledge and skill to use e-learning during the COVID19 pandemic. *

한 개의 타원형만 표시합니다.

$\begin{array}{lllll}1 & 2 & 3 & 4 & 5\end{array}$

strongly disagree $\square \square \square \square$ strongly agree

14. I am not confident in using e-learning during the COVID-19 pandemic. * 한 개의 타원형만 표시합니다.

$\begin{array}{lllllll}1 & 2 & 3 & 4 & 5 & \\ \text { strongly disagree } & \square & \square & \square & \square \text { strongly agree }\end{array}$

(C)Authors

This work is licensed under a Creative Commons Attribution-NonCommercial-NoDerivatives 4.0 International License (CC BY-NC-ND 4.0). 
15. I have experience in using e-learning. *

한 개의 타원형만 표시합니다.

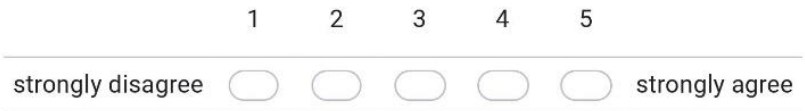

16. I believe that the use of e-learning in teaching is not useful during this pandemic. *

한 개의 타원형만 표시합니다.

\begin{tabular}{lllllll}
1 & 2 & 3 & 4 & 5 & \\
\hline strongly disagree & $\square$ & $\square$ & $\square$
\end{tabular}

17. The use of e-learning during this pandemic is not convenient for me. * 한 개의 타원형만 표시합니다.

$\begin{array}{lllll}1 & 2 & 3 & 4 & 5\end{array}$

strongly disagree $\square \bigcirc \bigcirc$ strongly agree

18. I feel confident in responding to student questions in online classes. * 한 개의 타원형만 표시합니다.

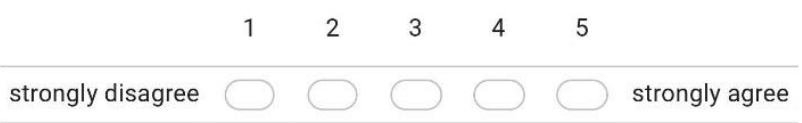


19. I feel confident in posting questions in online classes. *

한 개의 타원형만 표시합니다.

$\begin{array}{lllllll}1 & 2 & 3 & 4 & 5 & \\ \text { strongly disagree } & \square & \square & \square & \bigcirc \text { strongly agree }\end{array}$

20. I feel confident in using online tools (email, discussion) to effectively communicate with students. *

한 개의 타원형만 표시합니다.

\begin{tabular}{lllllll}
1 & 2 & 3 & 4 & 5 & \\
\hline strongly disagree & $\square$ & $\square$ & $\bigcirc$ & $\square$
\end{tabular}

21. I feel confident in expressing myself (emotions and humor) through text. * 한 개의 타원형만 표시합니다.

$$
\begin{array}{lllll}
1 & 2 & 3 & 4 & 5
\end{array}
$$

strongly disagree $\square \square \square$ strongly agree

22. I have felt increased stress as a result of recent changes to instructional methods (from traditional method to online instructional method). *

한 개의 타원형만 표시합니다.

$\begin{array}{lllllll}1 & 2 & 3 & 4 & 5 & \\ \text { strongly disagree } & \square & \square & \square & \square\end{array}$

\section{(c)Authors}

This work is licensed under a Creative Commons Attribution-NonCommercial-NoDerivatives 4.0 International License (CC BY-NC-ND 4.0). 
23. I am worried about how the recent changes to the instructional methods (from traditional method to online instructional method) have changed my teaching. *

한 개의 타원형만 표시합니다.

$\begin{array}{lllll}1 & 2 & 3 & 4 & 5\end{array}$

strongly disagree $\square \bigcirc$ strongly agree

24. I feel pressure as a result of recent changes to the instructional methods (from traditional method to online instructional method). *

한 개의 타원형만 표시합니다.

$\begin{array}{lllllll}1 & 2 & 3 & 4 & 5 & \\ \text { strongly disagree } & \square & \square & \square & \square \text { strongly agree }\end{array}$

25. In general, I find conducting online classes is interesting. *

한 개의 타원형만 표시합니다.

$\begin{array}{lllll}1 & 2 & 3 & 4 & 5\end{array}$

strongly disagree $\square \square \square$ strongly agree

26. I like conducting online classes. *

한 개의 타원형만 표시합니다.

$\begin{array}{lllllll}1 & 2 & 3 & 4 & 5 & \\ \text { strongly disagree } & \square & \square & \square & \square & \\ \text { strongly agree }\end{array}$

(c)Authors

This work is licensed under a Creative Commons Attribution-NonCommercial-NoDerivatives 4.0 International License (CC BY-NC-ND 4.0). 
27. I enjoy conducting online classes. *

한 개의 타원형만 표시합니다.

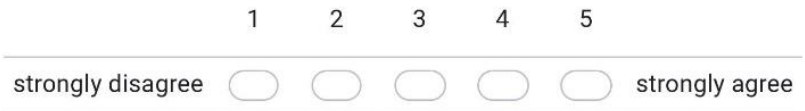

28. Conducting high quality online classes is useful for achieving my goal as a teacher. *

한 개의 타원형만 표시합니다.

\begin{tabular}{lllllll}
1 & 2 & 3 & 4 & 5 & \\
\hline strongly disagree & $\square$ & $\square$ & $\square$ & $\square$ strongly agree
\end{tabular}

29. Conducting high quality online classes is worthwhile for my teaching goal. * 한 개의 타원형만 표시합니다.

$\begin{array}{lllll}1 & 2 & 3 & 4 & 5\end{array}$

strongly disagree $\square \bigcirc \bigcirc$ strongly agree

30. Give your comments or impressions or feelings about online teaching. *

Thank you for your participation. Have a good day! :D 